\title{
The Isolation of Vibrio cholera and Other Enteric Bacteria with Molecular Characterization of Vibrio cholera during the Outbreak of Baghdad/Iraq in 2015
} \author{
Sarmad R. Naji1', Tuhama T. Mohammed ${ }^{1}$ \\ ${ }^{1}$ AL-Yarmouk Teaching Hospital, Baghdad, Iraq \\ ${ }^{2}$ Department of Gene Bank, University of AL-Nahrain, Baghdad, Iraq \\ Email: *dr_sarab_k@yahoo.com
}

Sarab K. Jameel1 ${ }^{*}$, Mostafa A. Shafek ${ }^{1}$, Ali M. Abdulmohsen², Nadira S. Mohamed²,

Received 19 June 2016; accepted 8 August 2016; published 11 August 2016

Copyright (C) 2016 by authors and Scientific Research Publishing Inc.

This work is licensed under the Creative Commons Attribution International License (CC BY). http://creativecommons.org/licenses/by/4.0/

\section{(c) (i) Open Access}

\begin{abstract}
Vibrio cholera, causing acute watery diarrhea known as cholera disease, affects all ages and both genders. Cholera infection outbreaks in Iraq have been reported for several years. The recent cholera outbreak, emerged throughout 2015, was investigated using bacteriological laboratory tests, singleplex and multiplex PCR technique for the detection of $V$. cholera from stool samples. Furthermore the toxigenic potential coupled with the antibiotic susceptibility test for cholera and other bacteria were also investigated. The stool samples were collected from 5698 patients admitted to Al-Yarmouk Teaching hospital and health care centers in Baghdad/Al-Karkh, Iraq, from the $1^{\text {st }}$ of August to the $30^{\text {th }}$ of December 2015. The $V$. cholera was isolated from 194 cases $(3.4 \%$ of the cases age between 21 - 50 years). In addition, other enteric infections: Salmonellosis and Shigellosis 7 and 21 respectively, protozoan parasite Giardia lamblia and Entamoeba histolytica 2 and 43 cases respectively were also reported. High percentage of $V$. cholera infection was detected in October (122 cases, 62.8\%), compared with other enteric infections that show high percentage of diarrheal disease in September and November. The results have confirmed that the cholera outbreak was caused by $V$. cholera 01 , biotype El Tor, and serotype Inaba. Seven virulence genes were identified $c t x A$, toxR, zot, ace, rfb01, tcpA and ompW. Moreover, the cholera isolated strains were found sensitive to most antibiotic but resistant to nalidixic acid.
\end{abstract}

\section{Keywords}

V. cholera, Enteric Bacteria, Diarrhea Outbreak, Virulence Factor Genes, Molecular Identification,

*Corresponding author.

How to cite this paper: Jameel, S.K., Shafek, M.A., Abdulmohsen, A.M., Mohamed, N.S., Naji, S.R. and Mohammed, T.T. (2016) The Isolation of Vibrio cholera and Other Enteric Bacteria with Molecular Characterization of Vibrio cholera during the Outbreak of Baghdad/Iraq in 2015. Advances in Microbiology, 6, 699-715. http://dx.doi.org/10.4236/aim.2016.69069 


\section{Antimicrobial Sensitivity Test}

\section{Introduction}

Across the globe, infectious gastroenteritis (IGE) is a cause of global morbidity and mortality [1]. There are different etiologic agents that may cause IGE, including bacteria (Shigella, Campylobacter jejuni, Vibrio cholera $\mathrm{O} 1$ and 139 and other pathogenic Vibrios), viruses (rotavirus) and parasites ((protozoa: Giardia lamblia and Entamoeba histolytica) and helminthes) [2] [3]. Diarrhea is the dominant symptom of IGE, it represent more than $30 \%$ of hospitalizations morbidity [4], usually begins as acute watery or as dysentery bloody [5] [6], then leads to weight loss and may cause dehydration [7]. It's common in all age groups especially in infants and young children, because their digestive and immune systems are still developing and vulnerable to infection [8]. Enteric infections commonly transmitted through fecal-oral route (food and water contamination) [9]. To reduce this risk of the transmission, a good personal hygiene practice and good food handling practice are required [10]. However, it has been suggested that people who have enteric infections should be excluded from the work in a high risk setting (i.e. workers in health care, residential care and child care, food handlers, young children in child care, etc.) because those people represent a source of IGE even when they are clinically asymptomatic for 24 - 48 hrs and have normal stools test [11].

Vibrios are Gram-negative, highly motile curved rods with a single polar flagellum. They tolerate alkaline media that kill most intestinal commensal, but they are sensitive to acid. Numerous free-living vibrios are known, some potentially pathogenic. Until 1992, cholera was caused by only two serotypes, Inaba (AC) and Ogawa (AB), and two biotypes, classical and El Tor, of toxigenic O group $1 \mathrm{~V}$. cholera [12]-[14]. The bacterium may be identified by agglutination in $\mathrm{O}$ group 1-specific antiserum directed against the lipopolysaccharide component of the cell wall and by the demonstration of their enterotoxigenicity. In 1992, cholera caused by serogroup O139 (synonym "Bengal” the 139 and latest serogroup of V. cholera to be identified) emerged in epidemic proportions in India and Bangladesh. This serovar is identified by 1) absence of agglutination in $\mathrm{O}$ group 1 specific antiserum; 2) by agglutination in O group 139 specific antiserum; and 3) by the presence of a capsule [12].

The pathogenesis of $V$. cholera involves infection, reaching and colonizing in the epithelium of the small intestine. Within the intestine, where $V$. cholera express a variety of extracellular aggressive virulence factors, toxin coregulated pilus (TCP) and cholera toxin (CT) are essential for the colonization of the host and enterotoxicity, respectively [15] [16]. The virulence cascade toxR protein of $V$. cholera regulates the expression of several virulence factors including TCP that play important roles in the pathogenesis of cholera [17]. There are at least 6 virulence genes in $V$. cholera. These genes are the regulator factors and they are: tox $\mathrm{R}$, cholera toxin $(c t x \mathrm{~A})$, toxin coregulated pilus (tcpA), outer membrane protein $(\mathrm{OmpW})$, accessory cholera toxin (ace), zonulaoccludens toxin (zot) and $\mathrm{O} 1$ somatic antigen ( $\mathrm{rbO} 1$ ) which may commonly be found in all $V$. cholera species [18] [19]. People infected with cholera may suffer from different clinical symptoms including vomiting, fever, hypotension, removes essential body fluids, salts and vital nutrients. They may also suffer from body spasm, paralysis and fainting [20] [21]. Patients with severe dehydration, as a result of diarrhea caused by V. cholera, are recognized and they are either treated with oral rehydration fluid and/or intravenous fluid replacement, while antibiotics are not a necessary part of cholera treatment, because it may contributes to the emergence of resistance [22] [23]. Other researchers confirmed to use different antibiotics like trimethoprim-sulfamethoxazole, tetracycline, azithromycin, erythromycin, and ampicillin, which are very useful to reduce the duration of cholera diarrhea [15] [24].

To assist with confirmation of $V$. cholera; numerous diagnostic laboratory tests are applied [25] [26] including stool culture, biochemical test, specialized microscopy, serological test and these include polyvalent, Ogawa, Inaba antisera testing, and singleplex PCR, conventional coupled PCR or real-time PCR with fluorescence; for detecting different genes encoding to the different $V$. cholera toxins [18] [27].

\section{Cholera Outbreak in Iraq 2015}

In the last two decades, the cholera disease in Iraq is represented as an epidemics infection [28]. This has worsened 
especially after 1991 the first Gulf war when the cholera became endemic in all governorates of Iraq [29]. Between 2007 and 2009, many Iraqi people suffered from the cholera disease [24]. At that time, V. cholera O1 serotype (Inaba) was detected and confirmed for. In 2012, V. cholera O1 serotype (Ogawa) was detected and confirmed for [14] [30]. The climatic factors in Iraq may play a role in $V$. cholera outbreaks and also in the strength, duration, or appearance of these annual seasonal patterns, especially in countries near the equator which have higher and more constant temperatures and thus may encourage the constant level of cholera outbreaks mostly in the warmer months [31]. Furthermore, most of wastewater treatment in Iraq has not been functioned according to golden roles due to the war. This has caused a huge contamination with $V$. cholera in freshwater across the country. Between September 23 to November 6, 2015, 2651 cholera cases have been reported and confirmed in Baghdad and in other 14 Iraqi governorates; such as serogroup O1 (Inaba serotype) with a few cases of (Ogawa serotype) which affected different age groups and genders [32]. Accordingly, the WHO recommended the necessity to improve water supplies and the infrastructures as well as to equip electricity and sanitary disposal of feces in addition to the betterment of the physical and social conditions especially in the refugee camps, for the control of $V$. cholera outbreaks [33] [34].

The aim of this study is the isolation and identification of the enteric pathogen, the $V$. cholera in particular, to determine the main source of the diarrhea with the toxigenic (virulent genes) local isolates of Vibrio cholera from the patients admitted to Al-Yarmouk Teaching hospital and from Medical Sectors (health care centers) and identify the antibiotic susceptibility for Vibrio cholera and other enteric bacterial isolates.

\section{Materials and Methods}

\subsection{Collection of Stool Specimens}

Suspected cholera stool specimens were collected from patients at Al-Yarmouk Teaching hospital and 38 health care centers, Baghdad/Al-Karkh. In this surveillance system, every patient with diarrhea attending the hospital or the care centersis screened for major enteric pathogens. According to the hospital surveillance records, $82 \%$ of the patients report to Al-Yarmouk Teaching hospital and 38 health care centers within 1day after the first episode of acute diarrhea, while $18 \%$ have report between 1 and 2 days. For this study, water stool samples were collected aseptically from 5698 patients who had no prior medication, from $1^{\text {st }}$ of August to $30^{\text {th }}$ of December 2015 and the participants are males and females.

The stool samples that are collected without transport media were immediately transported to the laboratory within $30 \mathrm{~min}$; while from health care center, Cary-Blair transport medium was used. All samples (except stool swab) were examined microscopically for the presence of red and white blood cells, yeast and parasites to assess colonic inflammatory processes. However, to detect ova and parasites trophozoites and/or cyst like Giardia lamblia, and Entamoeba histolytica, the Lugol iodine solution was used [2] [35].

\subsection{Bacterial Culture, Isolation and Identification}

Collected stool specimens were immediately placed into alkaline peptone water (APW; Biomark ${ }^{\mathrm{TM}}$, India) at pH 8.5 as an enrichment media for vibrios [36], and incubated at $37^{\circ} \mathrm{C}$ for 6 hrs., then streaked using an inoculating loop onto selective media thiosulfate citrate bile salts sucrose (TCBS), MacConkey agar, and blood agar (Biomark $^{\mathrm{TM}}$, India) and incubated at $37^{\circ} \mathrm{C}$ for 18 to $24 \mathrm{~h}$ [37].

Regarding the isolation of Salmonella, the stool samples were inoculated into selective enrichment media tetrathionate broth with Iodine-iodide solution (Ibn Al-betar Research Center, Iraq) and incubated at $37^{\circ} \mathrm{C}$ for 18 to 24 hrs., then streaked using an inoculating loop onto selective media, Xylose lysine deoxycholate agar (XLD; Conda, Spain) and Hektoen agar (HK; Biorex, UK) then incubated at $37^{\circ} \mathrm{C}$ for 18 to 24 hrs. For Shigella, stool sample have been inoculated directly into the selective media [38] [39].

\subsection{Biochemical Tests}

All bacterial isolates Vibrio, Salmonella and Shigella were diagnosed according to their biochemical tests the Oxidase, Indole, kligler Iron agar (KIg)-slant-(sugar ferment-gas-H2S), Urease, Simmon citrate media, API 20 E and API 20 NE (Biomereumix, France). In addition to Cholera Red, String test and Polymyxin B disc were done for Vibrios [15]. All bacterial isolates were sent to the Central Public Health Laboratory (CPHL), Ministry of Health/Baghdad-Iraq to prove it Vibrio cholera, Salmonella and Shigella. 


\subsection{Serogrouping}

$V$. cholera colonies from KIg; (Biorex, UK) slant were tested to identify their serogroups using slide agglutination with polyvalent anti-Ogawa and anti-Inaba antisera (Denka seiken co. LTP-JAPAN) [40]. V. cholera O1 were preserved at $-20^{\circ} \mathrm{C}$ in glycerol for subsequent detection of $V$. cholera by multiplex PCR.

\subsection{DNA Preparation}

DNA extraction was carried out according to the enrichment by culturing in alkaline peptone water (1\% Bacto Peptone, $0.5 \% \mathrm{NaCl}, 0.07 \% \mathrm{Na}_{2} \mathrm{CO}_{3}, 0.01 \% \mathrm{KNO}_{2}$, $\mathrm{pH}$ 8.6) for $24 \mathrm{hrs}$. at $37^{\circ} \mathrm{C}$. Grown cultures were plated on TCBS agar plates and Kliglar iron slant. All isolates were routinely grown on Luria-Bertani (LB; Oxoid, UK) agar throughout the study. The Wizard ${ }^{\circledR}$ Genomic DNA Purification Kit (Promega, USA) was used according to the manufacturer's instructions. The $V$. cholera DNA detection were done using agarose gel electrophoresis which viewed with the red safe DNA stain and UV transilluminator (BioRad, USA).

\subsection{PCR Assays}

The PCR reaction was in $40 \mu \mathrm{l}$ of a 5 X FIREPol ${ }^{\circledR}$ Master Mix Ready to Load (solisBioDyne). Optimization of multiplex PCR was accomplished after several trials. Amplification was conducted using the following conditions: 1 cycle pre-denaturation at $95^{\circ} \mathrm{C}$ for $10 \mathrm{~min}, 35$ cycles of secondary denaturation at $95^{\circ} \mathrm{C}$ for $1 \mathrm{~min}$, annealing at $61.5^{\circ} \mathrm{C}$ for $1 \mathrm{~min}$, extension at $72^{\circ} \mathrm{C}$ for $1.2 \mathrm{~min}$, and final extension at $72^{\circ} \mathrm{C}$ for $10 \mathrm{~min}$. The amplified products were separated with $2.5 \%$ agarose gel and viewed using transilluminator (BioRad, USA).

\subsection{Sequencing and Data Analysis}

For the genes (ctxA, tcpA, ace, $r f b \mathrm{O} 1$, toxR, ompW and zot) using the cleanup PCR by (microClean,) using genetic analyzer 3100 (Applied Biosystems, USA) data were analyzed using Sequencing Analysis 5.2. The genes sequences submitted to NCBI/Gene bank database with accession numbers KX096224-KX096236, respectively.

\subsection{Antibiotic Susceptibility Profile of Bacterial Isolates}

All bacterial isolates were subjected to Kirby-Bauer method for susceptibility test, using disk diffusion technique; it was accomplished on Muller-Hinton agar [41]. For V. cholera, the following antibiotics are used: amikacin, ampicillin, cephalothin, cefotaxime, chloramphenicol, gentamicin, erythromycin, nalidixicacid, and tetracycline (Al-Razi Diagnostics Center/Iraq and Bioanalys /Ankara-Turkay). For Salmoella and Shigella the following antibiotics were used amoxicillin/clavulanic acid, tetracycline, ciprofloxicin, cefotaxime, ceftriaxone, azothromycin, aztreonam, co-trimoxazole, amoxicillin, ampicillin, chloramphenicol, imipenem (Al-Razi Diagnostics Center/Iraq and Bioanalys /Ankara-Turkay) [24] [42]-[44].

\subsection{Statistical Analysis}

Data were submitted to statistical analysis using EpiInfo-6 software program. Tables of frequency and percentage were issued. Chi-square test was calculated to explore the significance of the relationship between different variables, $P$ value $\leq 0.05$ was considered as positive level of significance.

\section{Results}

\subsection{Isolates}

From $1^{\text {st }}$ of August to $30^{\text {th }}$ of December 2015, 5698 stool samples were examined. The result was 194 as $V$. cholera, 21 as Shigella spp. (mostly Shig. flexneri), and 7 Salmonella spp. (mostly Sal. typhi). All Vibrio cholera isolates belong to the pattern of O1 serogroup, biotype-El-Tor, serotype Inaba. Protozoan parasite Giardia lamblia 2and Entamoeba histolytica 43 were also reported.

\subsection{Infection Pattern and Seasonality}

It is clear that Table 1 shows the significant results $(\mathrm{P}<0.05)$ of cholera infection. Two peaks were detected in 
different months: the first peak in September (57 cases) and increased in October (122 cases), followed by the gradual decline in November (14 cases) with only one case in August, finally, in December, no positive case has been recorded. Table 2 reveals that there is no-significant result $(P>0.05)$ of cholera infection and other enteric pathogen between the two genders. From 267 of different pathogens present in the study, Table 3 clearly shows that the highest percentage of $V$. cholera infection has occurred during October (122 cases (62.9\%) compared with the highest percentage of E. histolytica (28 cases (65.1\%) and Shigella infection (7 cases (33.3\%) in November. Regarding Salmonella, there were only 3 cases reported (42.8\%) during September. Concerning G. lamblia, the results revealed only 2 cases distributed in November and December.

The results in Table 4 demonstrate that the cholera infections are distributed for all age groups by both gender $(\mathrm{P}>0.05)$. Moreover, the highest percentage of cholera infections was found in the age group of 21 - 30 y (56

Table 1. Distribution of positive cholera cases according to month of occurrence and gender.

\begin{tabular}{|c|c|c|c|c|c|}
\hline \multicolumn{2}{|c|}{ Variable } & \multirow{2}{*}{$\begin{array}{c}\begin{array}{c}\text { Positive } V \text {. cholera } \\
\text { No. (\%) }\end{array} \\
1(0.3)\end{array}$} & \multirow{2}{*}{$\begin{array}{c}\begin{array}{c}\text { Negative } V \text {. cholera } \\
\text { No. (\%) }\end{array} \\
292(99.7)\end{array}$} & \multirow{2}{*}{$\begin{array}{c}\text { Total } \\
\text { No. (\%) }\end{array}$} & \multirow[t]{2}{*}{ P-value ${ }^{*}$} \\
\hline \multirow{6}{*}{ Month $^{* *}$} & August & & & & \\
\hline & September & $57(4.5)$ & 1207 (95.5) & $1264(100)$ & \multirow{5}{*}{$\begin{array}{c}0.000001 \\
\mathrm{df}=3\end{array}$} \\
\hline & October & $122(4.5)$ & 2575 (95.5) & 2697 (100) & \\
\hline & November & $14(1.4)$ & 960 (98.6) & 974 (100) & \\
\hline & December $^{* *}$ & - & $470(100)$ & $470(100)$ & \\
\hline & Total & 194 (3.4) & 5504 (96.6) & $5698(100)$ & \\
\hline \multirow{3}{*}{ Gender } & Male & 107 (3.7) & 2785 (96.3) & $2892(100)$ & \multirow{3}{*}{$\begin{array}{l}0.212 \\
\mathrm{df}=1\end{array}$} \\
\hline & Female & $87(3.1)$ & 2719 (96.9) & $2806(100)$ & \\
\hline & total & 194 (3.4) & 5504 (96.6) & $5698(100)$ & \\
\hline
\end{tabular}

** December doesn't included in the statistical analysis because there is no cholera case.

Table 2. Presence of different pathogens in the study stool sample by gender.

\begin{tabular}{cccc}
\hline Pathogen & Male No. (\%) & Female No. (\%) & Total No. (\%) \\
\hline V. cholera & $107(55.2)$ & $87(44.8)$ & $194(100)$ \\
Salmonella & $2(28.6)$ & $5(71.4)$ & $7(100)$ \\
Shigella & $10(47.6)$ & $11(52.4)$ & $21(100)$ \\
Entamoeba histolytica & $22(51.2)$ & $21(48.8)$ & $43(100)$ \\
Giardia lamblia & $1(50)$ & $1(50)$ & $2(100)$ \\
Total & $142(53.2)$ & $125(46.8)$ & $267(100)$ \\
\hline
\end{tabular}

Table 3. Presence of different pathogens in the study stool sample according to month.

\begin{tabular}{cccccccc} 
Months & No. & V. cholera & Sal. & Shi. & E.H & G.L. & Total \\
\hline August & 293 & $1(0.5)$ & $2(28.6)$ & $4(19.0)$ & - & - & 7 \\
September & 1264 & $57(29.4)$ & $3(42.8)$ & $5(23.8)$ & $1(2.3)$ & - & 66 \\
October & 2697 & $122(62.9)$ & $2(28.6)$ & $4(19.0)$ & $5(11.6)$ & - & 133 \\
November & 974 & $14(7.2)$ & - & $7(33.3)$ & $28(65.1)$ & $1(50)$ & 50 \\
December & 470 & - & - & $1(4.8)$ & $9(20.9)$ & $1(50)$ & 11 \\
Total & 5698 & $194(100)$ & $7(100)$ & $21(100)$ & $43(100)$ & $2(100)$ & 267 \\
\hline
\end{tabular}

Sal. $=$ Salmonella, Shi. $=$ Shigella, E.H. = Entamoeba histolytica, G.L. = Giardia lamblia. 
cases; 28.9\%), followed by the age groups of 31 - 40 y (42 cases; 21.7\%), and 41 - 50 y (35 cases; 18.0\%), while less cholera infections have occurred in the age groups below 10 and over 60 y, 13.7 and 13 cases (3.6\% and $6.7 \%)$ respectively. In general, for the age groups between 11 - $20 \mathrm{y}$ and 51 - $60 \mathrm{y}$, the cholera infection has affected all of them equally.

\subsection{The Distribution of Patients with Cholera According to the Different Sources (Sector/District, Medical Center and Hospital)}

The distribution of cholera infection by gender and sectors/districts is illustrated in Table 5. The highest percentages were from Al-Alam sector 74 cases (38.1\%) followed by Al-Amil sector 54 cases (27.8\%) then Al-Dora sector 38 cases (19.6\%), while Al-Karkh and Al-Adel sectors, recorded the convergent results $7.7 \%$ and $6.7 \%$, respectively. Furthermore, there is no-significant difference between the cholera infection for gender and the residence in different districts $(\mathrm{P}>0.05)$. Nevertheless, statistically high significant value $(\mathrm{P}=0.0001)$ between 154 positive cases infected with $V$. cholera (9.9\%) were admitted to Al-Yarmouk Teaching hospital, compared with 40 positive cases infected with $V$. cholera $(0.96 \%)$ from other medical health care centers (Table 6).

Table 4. Distribution of cholera cases according to age groups and gender.

\begin{tabular}{|c|c|c|c|c|}
\hline \multirow{3}{*}{ Age/years } & \multicolumn{2}{|c|}{ Positive V. cholera } & \multirow{3}{*}{ Total positive } & \multirow{3}{*}{ P-value } \\
\hline & Male & Female & & \\
\hline & (+ve) & (+ve) & & \\
\hline-10 & 1 & 6 & 7 & \multirow{8}{*}{$\begin{array}{r}0.273 \\
d f=5\end{array}$} \\
\hline $11-20$ & 15 & 5 & 20 & \\
\hline $21-30$ & 32 & 24 & 56 & \\
\hline $31-40$ & 24 & 18 & 42 & \\
\hline $41-50$ & 13 & 22 & 35 & \\
\hline $51-60$ & 13 & 8 & 21 & \\
\hline 61- & 9 & 4 & 13 & \\
\hline Total & 107 & 87 & 194 & \\
\hline
\end{tabular}

Table 5. Distribution the positive cases of Vibrio cholerae by gender and sectors.

\begin{tabular}{ccccc}
\hline \multirow{2}{*}{ Sector/district } & \multicolumn{2}{c}{ Positive V. cholera } & Total Positive & P-value $^{*}$ \\
\cline { 2 - 3 } & Male & Female & & \\
AL-Karkh & $12(80)$ & $3(20)$ & $15(7.7)$ & \\
AL-Adeel & $8(61.5)$ & $5(38.5)$ & $13(6.7)$ & 0.35 \\
AL-Amil & $28(51.9)$ & $26(48.1)$ & $54(27.8)$ & $d f=4$ \\
AL-Alam & $40(54.1)$ & $34(45.9)$ & $74(38.1)$ & \\
AL-Dora & $19(50)$ & $19(50)$ & $38(19.6)$ & \\
Total & $107(55.2)$ & $87(44.8)$ & $194(100)$ & \\
\hline
\end{tabular}

Table 6. Distribution of examination results according to source of the sample.

\begin{tabular}{ccccc}
\hline Source of sample & Positive for $\boldsymbol{V}$. cholera & Negative for V. cholera & Total & P-value $^{*}$ \\
\hline $\begin{array}{c}\text { Medical health care centers } \\
\text { AL-Yarmouk Teaching } \\
\begin{array}{c}\text { Hospital } \\
\text { Total }\end{array}\end{array}$ & $40(0.96)$ & $4109(99.04)$ & 4149 & \\
\hline
\end{tabular}




\subsection{Primer Design}

The primer sequence was designed for ompW and zot genes in-silico using primer 3 algorithm and, as a result, good primers have appeared for the detection of these genes (Table 7). The primers for $c t x \mathrm{~A}$, ace, toxR, $r f b \mathrm{O} 1$ and tcpA genes were designed according to Fields, Goal and Rivera references [45]-[47].

\subsection{Genotyping by PCR}

The isolates $194 \mathrm{~V}$. choerae, in which only 35 isolates were confirmed genetically, have the ompW specific species gene (Figure 1). The detection of the toxigenic strain of $V$. cholera that possessed the CTX genetic element

Table 7. Primer sets used for PCR assay and the amplicons size.

\begin{tabular}{|c|c|c|c|c|c|}
\hline NO & Primer & & Primer sequence & Amplicons size & Reference \\
\hline 1 & omp $\mathrm{W}$ & $\mathrm{R}$ & $\begin{array}{l}\text { 5'-TGCCTCGGTAGTACCTAATGA-3' } \\
\text { 5'-GCACCAGCTTTGTAGGTTGC-3' }\end{array}$ & 486 bp & This study \\
\hline 2 & tcpA & $\begin{array}{l}\mathrm{F} \\
\mathrm{R}\end{array}$ & $\begin{array}{l}\text { 5'-CGTTGGCGGTCAGTCTTG-3' } \\
\text { 5'-CGGGCTTTCTTCTTGTTCG-3' }\end{array}$ & 805 bp & Goel et al. 2007 \\
\hline 3 & $r f b O 1$ & $\begin{array}{l}\mathrm{F} \\
\mathrm{R}\end{array}$ & $\begin{array}{l}\text { 5'-TCTATGTGCTGCGATTGGTG-3' } \\
\text { 5'-CCCCGAAAACCTAATGTGG-3' }\end{array}$ & 538 bp & Goel et al. 2007 \\
\hline 4 & toxR & $\mathrm{R}$ & $\begin{array}{l}\text { 5'-CCTTCGATCCCCTAAGCAATAC-3' } \\
\text { 5'-AGGGTTAGCAACGATGCGTAAG-3' }\end{array}$ & 779 bp & Rivera et al. 2001 \\
\hline 5 & $\operatorname{ctxA}$ & $\begin{array}{l}\mathrm{F} \\
\mathrm{R}\end{array}$ & $\begin{array}{l}\text { 5'-CGGGCAGATTCTAGACCTCCTG-3' } \\
\text { 5'-CGATGATCTTGGAGCATTCCCAC-3' }\end{array}$ & 564 bp & Fields et al.1992 \\
\hline 6 & ace & $\begin{array}{l}\mathrm{F} \\
\mathrm{R}\end{array}$ & $\begin{array}{l}\text { 5'-TTGATGGCTTTACGTGGCTT-3' } \\
\text { 5'-GCGCTTGGTCTAACCCTAAA-3' }\end{array}$ & 198 bp & Rivera et al. 2001 \\
\hline 7 & zot & $\begin{array}{l}\mathrm{F} \\
\mathrm{R}\end{array}$ & $\begin{array}{l}\text { 5'-GGTGGCTTTTGACATGCATC-3' } \\
\text { 5'-CCAAATTGTCTACGAGGCGA-3' }\end{array}$ & 575 bp & This study \\
\hline
\end{tabular}

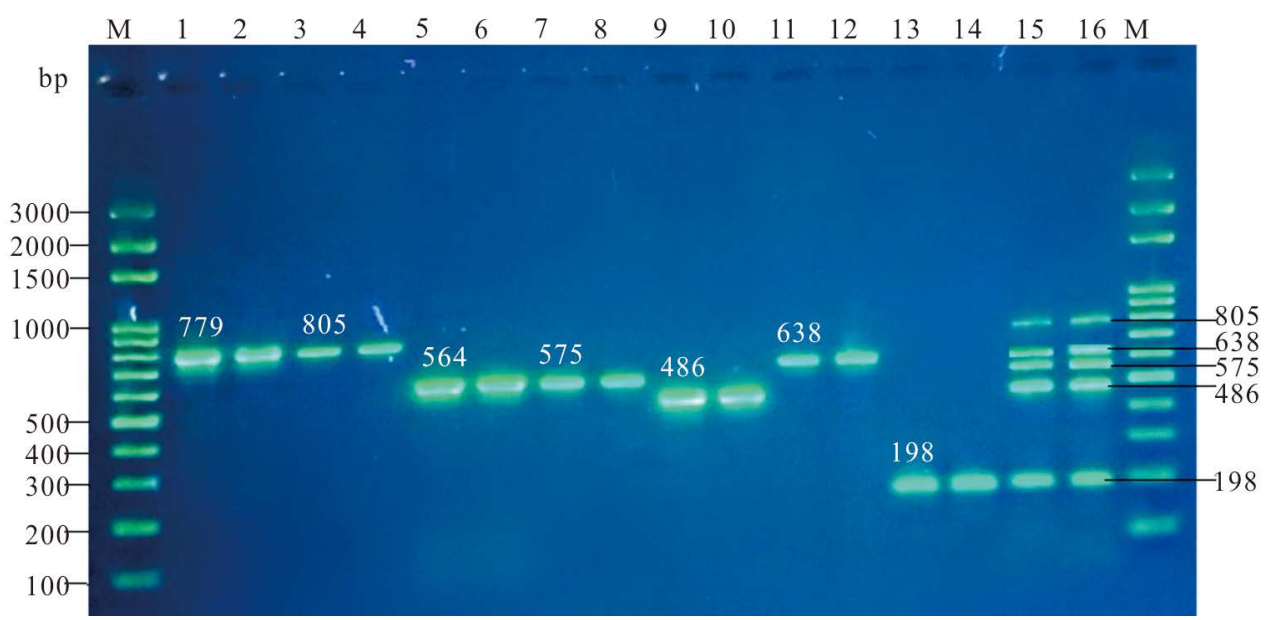

Figure 1. Agarose gel electrophoresis result of uniplex PCR products. Lane M: 100 bp ladder, lanes 1, 2 represent toxR gene PCR products (779 bp), lane 3,4 represent tcpA gene PCR products (805 bp), lane 5, 6 represent ctxA gene PCR products (564 bp), lane 7, 8 represent zot gene PCR products (575 bp), lane 9, 10 represent ompW gene PCR products (486 bp), lanes 11,12 represent $r f b O 1$ gene PCR products (638 bp), lane 13, 14 ace gene PCR products (198 bp), lanes 15, 16 represent multiplex of five gene (tcp, rfbO1, zot, ompW, ace respectively). Electrophoresis was carried out in $2.5 \%$ agarose gel supplied with Red safe DNA dye at (5 $\mathrm{V} / \mathrm{cm}$ ) for 2 hrs. 
contains ctxA gene, toxR, zot, ace, $r f b \mathrm{O} 1$, tcp and ompW genes using singleplex PCR for each single gene were tested and optimized for several trials till reached to the best reaction condition (Figure 1). Moreover, PCR analysis (Singleplex and Multiplex) revealed that all randomly 35 isolates tested are positive for $c t x \mathrm{~A}, t o x \mathrm{R}$, ace, $r f b O 1$, tcpA and ompW genes (100\%). In comparison, only 31 isolates (88.57\%) are positive for zot gene. Noteworthy, the ompW genes is a marker for the identification of $V$. cholera which was shown to be dominant in all of the investigated isolates.

\subsection{Antimicrobial Drug Susceptibility}

Disk diffusion testing demonstrated that all isolates of $V$. cholera O1 were highly sensitive (100\%) to ampicillin, cefotaxime + clavulanic acid and cephalothin, followed by chloramphenicol, gentamycin and amikacin (99\%) (Table 8). Nevertheless, cholera isolates show less sensitivity to tetracycline and erythromycin with the rate sensitivity of $37.6 \%$ and $12.4 \%$, respectively, whereas all were resistant to nalidixic acid (100\%).

The 21 isolates of Shigella and 7 isolates of Salmonella were sensitive (100\%) to ciprofloxacin, aztreonam, ampicillin, chloramphenicol and imipenem. Moreover, Salmonella alone is (100\%) sensitive to tetracycline, ceftriaxone, co-trimoxazole, but it shows less resistance to amoxicillin, amoxicillin + clavulanic acid (28.6\%, $14.3 \%$ ) respectively, in comparison with Shigella which shows high resistance to these two types of antibiotics (85.7\%, 76.2\%) respectively. In general both types of bacteria demonstrate acceptable degree of sensitivity test to cefotaxime and azithromycin (Table 9).

\section{Discussion}

Phenotypic results, obtained in this study, led to presumptive identification of the Baghdad/Al-Karkh 194 bacterial isolates as the $V$. cholera $\mathrm{O} 1$ serogroup, biotype El Tor and serotype Inaba. This finding is similar to that reported in Baghdad 2007 cholera outbreak and in Babylon in 2012 and 2014 [28] [37] [55]. This new variant of $V$. cholera was first reported in Bangladesh 2002 [48]. Since then, several studies have given reports on the prevalence of $V$. cholera variants in several Asian countries [49]-[54]. This cholera genotype did not exist prior to this period. These results give indication that Iraq cholera disease represents epidemics spreading from some neighboring countries visitors to holy shrine sites in Iraq [28]. This may be due to inadequate supplies and a shortage of health personnel, among other factors which provide adequate conditions for $V$. cholera O1, biotype El Tor, serotype Inaba to survive better in the warm environment and crowded areas which give better transmission from human to human by food and water since the El Tor strains have efficiency transmission from host to host when compared with classical cholera strains [56] [57].

\begin{tabular}{|c|c|c|c|}
\hline \multirow{3}{*}{ Antibiotic disc } & \multicolumn{3}{|c|}{ V. cholera isolates $(N=194)$} \\
\hline & Sensitive & Moderate & Resistant \\
\hline & No. (\%) & No. (\%) & No. (\%) \\
\hline Amikacin & $192(99)$ & $1(0.5)$ & $1(0.5)$ \\
\hline Ampicillin & $194(100)$ & - & - \\
\hline Chloramphenicol & $193(99.5)$ & - & $1(0.5)$ \\
\hline Cefotaxime + Clavulanic acid & $194(100)$ & - & - \\
\hline Cephalothin & $194(100)$ & - & - \\
\hline Erythromycin & $24(12.4)$ & $170(87.6)$ & - \\
\hline Gentamycin & 193 (99.5) & $1(0.5)$ & - \\
\hline Nalidixic acid & - & - & $194(100)$ \\
\hline Tetracyclin & $73(37.6)$ & $121(62.4)$ & - \\
\hline
\end{tabular}

$\mathrm{S}=$ sensitive, $\mathrm{M}=$ moderate sensitivity, $\mathrm{R}=$ Resistant. 
Table 9. The sensitivity test of Salmonella \& Shigella isolates to the antibiotics discs.

\begin{tabular}{cccccccc}
\hline \multirow{2}{*}{ Antibiotic disc } & \multicolumn{3}{c}{ Shigella sp (N = 21) } & \multicolumn{3}{c}{ Salmonella sp (N = 7) } \\
\cline { 2 - 7 } & S & M & R & S & M & R \\
\hline Amoxicillin + Clavulanic acid & $5(23.8)$ & - & $16(76.2)$ & $5(71.4)$ & $1(14.3)$ & $1(14.3)$ \\
Tetracyclin & $18(85.7)$ & - & $3(14.3)$ & $7(100)$ & - & - \\
Ciprofloxicin & $21(100)$ & - & - & $7(100)$ & - & - \\
Cefotaxime & $13(61.9)$ & - & $8(38.1)$ & $5(71.4)$ & - & $2(28.6)$ \\
Ceftriaxone & $20(95.2)$ & $1(4.8)$ & - & $7(100)$ & - & - \\
Azithromycin & $19(90.5)$ & - & $2(9.5)$ & $6(85.7)$ & $1(14.3)$ & - \\
Aztreonam & $21(100)$ & - & - & $7(100)$ & - & - \\
Co-Trimoxazole & $5(23.8)$ & $1(4.8)$ & $15(71.4)$ & $7(100)$ & - & - \\
Amoxicillin & $3(14.3)$ & - & $18(85.7)$ & $3(42.8)$ & $2(28.6)$ & $2(28.6)$ \\
Ampicillin & $21(100)$ & - & - & $7(100)$ & - & - \\
Chloramphenicol & $21(100)$ & - & - & $7(100)$ & - & - \\
Imipenem & $21(100)$ & - & - & $7(100)$ & - & - \\
\hline
\end{tabular}

$\mathrm{S}=$ sensitive, $\mathrm{M}=$ moderate sensitivity, $\mathrm{R}=$ Resistant.

In this context, it is noteworthy that the few studies suggested that most of the Iraqi cholera isolates mostly belong to Ogawa serotype and only few are Inaba serotype [32] [58]. Nevertheless, other studies conducted in Iraq revealed that 58 isolates out of $66 \mathrm{~V}$. cholera belong to the pattern under serum Inaba and only 5 isolates are ogawa and 3 isolates belonging to non-cholera vibrios [59]. However, our results are not in agreement with a study done in Baghdad during the 1999 outbreak of cholera [60] and in Haiti from 2010 to 2011 [61] which showed that Ogawa serotype is the predominant. These results may give observation about $V$. cholera serotype which may change epidemiologically when compared with the past decade [37].

In the current study, the rate of diarrhea is approximately similar in male and female. The analysis of this study revealed significant higher occurrence of $V$. cholera infection in September and October than the other months. The present results are consistent with other studies [31] [32]. Other studies described two annuals of El Tor cholera peaks; these are a smaller spring outbreak in April before the monsoons rains then a larger outbreak from September to December after the monsoon rains [62] [63]. The primary transmission of cholera to the humans have been enabled by several environmental factors such as temperature, salinity, nutrient concentrations, and the plankton in water, shellfish consumption, and aquatic ecosystems [64], due to ecological responses to recent climate change [62], in which current climate condition may enable $V$. cholera to persist in aquatic ecosystems during winter [31].

Other important enteric bacterial pathogens such as Salmonella and Shigella were also isolated in this study during August to October (Salmonella 7 and Shigella 21). Furthermore the current study also shows that E. histolytica and G. lamblia have a higher occurrence during November and December. It is well known that enteric infections, caused by the protozoan and bacteria, exhibit seasonal variation. Enteric bacterial infections rise in the summer and decline in the winter, in contrast to protozoan infection which has shifted towards autumn [65] $[66]$.

The incidence of diarrhea infections caused by enteric bacteria and protozoan occurred around the year and for the whole age groups [8] [34] [67]. They are considered as a waterborne and food-borne infection [66], that increase with the increase of temperature, especially in summer when there is water shortage, higher water consumption, outdoor activities and recreational water use such as camping or swimming, then spread infections person-to-person and may amplify outbreaks of enteric diarrhea disease [68]-[70]. These conditions, after 2003 are clearly visible in many parts in Iraq such as poor environmental sanitation, coupled with special events such as flood, famine, and refugee movements with overcrowded camps which may assist to increase enteric diarrhea 
diseases including cholera [71]-[73].

In the present study, 267 (4.7\%) enteric pathogens, including cholera and protozoa, were isolated out of 5698 diarrhea cases, while there have been 5431 (95.3\%) negative cases. The interpretation of this result is that the pathogen was present in the stool sample but was below the limit of detection of the assay. Furthermore, stool sample represent a complex matrix with multiple pathogenic microbes, and finding a rare entero-pathogen is inherently challenging [21] [74] [75]. Cholera infection was detected for all age groups and in both gender (P > 0.05). The highest percentage was found in adult age groups, while less percentage of cholera infection was found in children and older age groups, and in male (55.2\%) than in female (44.8\%). These percentages are widely acceptable for the cholera infection outbreak in 2015, which was confirmed that 2651 cases comprising of 1477 (55.7\%) males and 1174 (44.3\%) females, all age groups were included [32], and, similar to previous researches, it has been shown that age groups were ranged from 12 - 65 years old [76], and 54.4\% are male and $45.6 \%$ are female out of 160 cases of cholera infections [33]. On the other hand, these results are inconsistent with other results that reported cholera infections in age groups $<1$ year (16.3\%), 1 - 5 years $(62.5 \%)$ and $>5$ years (21.3\%) [28]. Interestingly, the studies in 1999, 2009 and 2014 reported that cholera usually affect the age group between 1 - 5 years and occasionally in the neonatal period 2 - 30 days [37] [58] [77]. It is worth noting that cholera infection in children is less likely to occur presumably due to protection afforded by secretory antibody in mother's milk [78]. Nevertheless it has been speculated that if cholera occurs in less than five years age, then it could be due to poor sanitation and educational measures of this age groups [79]. In contrast, older age groups appear to have less cholera infection and this could be related to their acquired immunity gained from repeated exposure of diseases whether symptomatic or asymptomatic infection [80] [81] and furthermore the recurrent infections of cholera are rare as a result of the role of local immune defense in the intestinal mucosa [78].

Regarding the distribution of patients with cholera in the west of Baghdad, the highest percentage of cholera was isolated from Al-Alam and Al-Amil sectors and less in Al-Dora, Al-Karkh, and Al-Adel sectors. Similar results were also reported for the above mentioned sectors of Baghdad [28] [33]. Cholera transmission is a result of fecal contamination of drinking-water which is closely linked to inadequate environmental management [58]. As a result of that, some sectors in Baghdad suffer from the shortage of municipal drinking water. Therefore, the people living in those sectors dig their own wells without using the adequate methods of water treatment, or they transfer their drinking water via unclean tankers [28]. On other hand, infrastructure destruction as a result of the multiple crises which Iraq has suffered from and events such as floods, famine and wars, displacement of populations to inadequate and overcrowded camps for internally displaced persons or refugees [82], all have participated to spread cholera in Iraq and it has become an epidemic that threatens other neighboring countries since bacterial pathogens can be transmitted via birds, air, foods, and rivers.

In the current study, 154 (9.9\%) positive cases for cholera infection were admitted to Al-Yarmouk Teaching hospital; and $40(0.96 \%)$ positive cases for cholera infection from the 38 medical health care centers. These samples were collected according to the cholera surveillance system of WHO. The results affirm that surveillance for cholera is a critical component to be controlled. Moreover, detecting and reporting the bacterial strains is important, especially new strains which have the potential to cause new epidemics. Cholera outbreaks must be detected quickly especially in areas that have recently experienced deterioration in water sanitation due to natural disasters, civil strife, or recently established refugee camps. Accordingly, appropriate and rapid responses should be undertaken, such as preparation of preparedness plans, training of healthcare staff and pre-positioning of supplies [83]-[85].

The PCR analysis revealed that all 35 isolates tested from $194 \mathrm{~V}$. cholera isolates were positive for ace, ctxA, ompW, rfbO1, tcpA and tox R genes (100\%), while only 31 isolates (88.57\%) were positive for zot gene. Similar results were also reported in 2013, 2015 and 2016 [86]-[89]. The presented findings agree with result published in 2007 [90] which revealed that all strains tested in multiplex PCR analysis showed positive for ace, ctxB, hlyA, ompU, ompW, rfbO1, rtx, tcpA, toxR and zot virulence genes. On the other hand, all the isolated 35 Vibrio were positive for the ompW gene. The ompW gene acts as an internal control for $V$. cholera and could be compatible with the biochemical and serological tests which are used to identify the suspects Vibrio isolate [91], which plays an important role in the physiology of these bacteria and has an impact on the rapid adaptation of the bacteria to the environment [92] representing a species-specific for $V$. cholera [86].

In general, the present study shows that all tested $V$. cholera isolates belong to $\mathrm{O} 1$ serogroup. The somatic $\mathrm{O}$-antigen biosynthesis gene was positive for O1serogroup ( $f f b \mathrm{O} 1$ ), in addition to $c t x \mathrm{~B}$, zot, tox $\mathrm{R}$ and ompW genes. Furthermore the cholera $\mathrm{O} 1$ isolates were positive form accessory cholera toxin (ace) and toxin 
coregulated pilus (tcp). Cholera pathogenesis is a complex process and involves synergism of several genes, although cholera toxin (CT) is supposed to be the most important epidemic marker among various toxins produced by $V$. cholera [91]. Yet the combination of two target genes including $c t x \mathrm{~A}$ and $r f b \mathrm{O} 1$ can be used for differentiation of toxigenic $V$. cholerae $\mathrm{O} 1$ from non-toxigenic because $c t x A$ gene is mainly responsible for watery diarrhea of toxigenic $V$. cholera [93]. It was found that both clinical and environmental $V$. cholera strains carriying ctxA, tcpA, ace and zot genes belonged to El Tor biotype [94]. Therefore, we can conclude that, in the present study, the molecular results are compatible with the bacteriology and serology results which indicated that Baghdad/ Al-Karkh section cholera outbreaks in 2015 was caused by a toxigenic V. cholerae O1 the El Tor-Inaba. Thus, several studies have shown that the patients who suffered from moderate cholera diarrhea, associated with isolated $V$. cholera, lack the zot gene which is considered acceptable because of the potential function of this gene due to the increase of the permeability of the mucosa in small intestinal by affecting the structure of the intercellular tight junction [95]. On other hand, the non-enterotoxigenic V. cholerae cells that lack ace, zot, and ctx genes do not cause diarrhea in volunteers. Interestingly, the presence of ToxR protein is important for the regulation and function of other virulence genes in pathogenic V. cholera [86] [89] [96] [97].

The current study shows that cholera isolates are highly sensitive to ampicillin, cefotaxime + clavulanic acid and cephalothin, chloramphenicol, gentamycin and amikacin (99\% - 100\%), whilst, they are less sensitive to tetracycline (37.6\%) and erythromycin (12.4\%) and completely resistant to nalidixic acid (100\%). It is interesting to find that the results of this study ware close to the results of other studies reported by several researchers [15] [20] [28] [98]. Yet other researchers reported that cholera is sensitive to ampicillin (49.4\%), tetracycline (5\%), gentamycin (31.2\%), trimetheprim (68.8\%), erythromycin (38.7\%) and nalidixic acid (69.4\%) [33] [58] [99] [100]. The variation in the results attributed to the difference of race, ethnicity, age, travel, and species [43]. Clearly $V$. cholera was found resistant to a commonly used antibiotics such as tetracycline, erythromycin and sensitive to ceftriaxone, cefixim; such behavior may threat through a higher secondary infection rate and by causing illness of longer duration [33]. In general, it was found that the resistance genes are located on large conjugative elements (SXT constins) that are integrated into prfC on the $V$. cholera chromosome [100], and this finding have opened space for more investigations and discussion for studying the integrating conjugative elements as well as the mobile genetic elements that can potentially mediate transfer of antimicrobial drug resistance [61] [101].

Regarding Shigella isolates, they were found to be sensitive to ciprofloxacin, aztreonam, ampicillin, chloramphenicol and imipenem, tetracycline, ceftriaxone, cefotaxime and azithromycin and they are relatively resistant to co-trimoxazole, amoxicillin and amoxicillin + clavulanic acid. Similar results were also reported [9] [43]. Overusing antibiotics to treat shigellosis may contribute to make this bacterium more resistant to the antibiotics [102]-[104]. Moreover, Salmonella isolates showed sensitivity to most of the above mentioned antibiotics [42] [105] [106].

\section{Conclusion and Recommendation}

Cholera isolates were identified as Vibrio cholera $\mathrm{O} 1$ biotype- El Tor serotype Inaba and these isolates harbored various toxigenic and pathogenic genes (tox $, c t x \mathrm{~A}, t c p \mathrm{~A}, o m p \mathrm{~W}$, ace, zot, rfbO1) and recorded in the NCBIas an Iraqi cholera isolates outbreaks in 2015. The study revealed that the highest rate of cholera infection was during September to October with the highest percentage rate among adults aged 21 - 50 years. Beside cholera infection, several enteric pathogens were isolated in September to November.

The current study emphasizes the importance to provide a safe drinking-water from a plants and water projects that utilize chlorine for disinfection. Also, it is important to encourage the usage of novel technologies in the disinfection of water. Moreover, there should be strict and accurate liquid waste disposal through competent sewage system to prevent direct throwing of (untreated) waste into the river. Application of the novel processing technique like phages biotechnology (phages-virus) has the potential to improve liquid waste treatment.

Health education plays an important role in the prevention of the disease; better understanding of the disease, identification of mode of transmission, and self-hygiene are the main items in this program.

Furthermore, emphasizing the importance of the adoption of molecular technologies, namely PCR for rapid, qualitative and quantitative cholera diagnosis to replace the microbiological culture media that are time consuming. 


\section{Acknowledgements}

Grateful thanks to Dr. Ali H. Hayawi for his help in implementing the statistical aspects of this study and to the biologist Aseel K. Hamzah for unlimited cooperation and assistance in the preparation of all culture media required to complete this work.

\section{References}

[1] Liu, L., Johnson, H.L., Cousens, S., Perin, J., Scott, S., Lawn, J.E., Rudan, I., Campbell, H., Cibulskis, R., Li, M., Mathers, C. and Black, R.E. (2012) Child Health Epidemiology Reference Group of, WHO and UNICEF; Global, Regional, and National Causes of Child Mortality: An Updated Systematic Analysis for 2010 with Time Trends since 2000. The Lancet, 379, 2151-2161. http://dx.doi.org/10.1016/S0140-6736(12)60560-1

[2] Stoll, B.J., Glass, R.I., Banu, H., Khan, M.I.H. and Ahmed, M. (1983) Value of Stool Examination in Patients with Diarrhea. British Medical Journal, 286, 2037-2040. http://dx.doi.org/10.1136/bmj.286.6383.2037

[3] Guerrant, R.L., Van Gilder, T., Steiner, T.S., Thielman, N.M., Slutsker, L., Tauxe, R.V., Hennessy, T., Griffin, P.M., DuPont, H., Sack, R.B., Tarr, P., Neill, M., Nachamkin, I., Reller, L.B., Osterholm, M.T., Bennish, M.L. and Pickering, L.K. (2001) Practice Guidelines for the Management of Infectious Diarrhea. Clinical Infectious Diseases, 32, 331-351. http://dx.doi.org/10.1086/318514

[4] Noaman, A.A. (2013) Acute and Chronic Diarrhea among Hospitalized Infants Aged (1-12) Months. Diyala Journal of Pure Science, 10, 1-10.

[5] Keusch, G.T., Fontaine, O., Bhargava, A., Boschi-Pinto, C., Bhutta, Z.A., Gotuzzo, E., Rivera, J., Chow, J., ShahidSalles, S. and Laxminarayan, R. (2006) Diarrheal Diseases. In: Jamison, D.T., Breman, J.G., Measham, A.R., Alleyne, G., Claeson, M., Evans, D.B., Jha, P., Mills, A. and Musgrove, P., Eds., Disease Control Priorities in Developing Countries, 2nd Edition, World Bank, Washington, DC, Chapter 19.

[6] Indian Academy of Pediatrics (2011) Chronic and Persistent Diarrhea in Infants and Young Children: Status Statement. Indian Pediatrics, 48, 37-42. http://dx.doi.org/10.1007/s13312-011-0018-9

[7] Al-Badri, A.A., Al Ammary, M.A.F, Al-Badawi, G.G. and Al-Azawi, S.A. (2007) Relation between Behavioral Factors, Malnutrition and Persistent Diarrhea in Children under Two Years of Age: A Hospital Study. Journal of the Faculty of Medicine Baghdad, 2249, 22-23.

[8] Abu-Ragheef, L.F. and Hussein A.K.A. (2007) Incidence of Seasonal Diarrhea among Children at Child's Central Hospital. Science Journal Nursing, 20, 20-26.

[9] Kimura, A.C., Johnson, K., Palumbo, M.S., Hopkins, J., Boase, J.C., Reporter, R., Goldoft, M., Stefonek, K.R., Farrar, J.A., Van Gilder, T.J. and Vugia, D.J. (2004) Multistate Shigellosis Outbreak and Commercially Prepared Food, United States. Emerging Infectious Diseases, 10, 1147-1149. http://dx.doi.org/10.3201/eid1006.030599

[10] Harker, C. (2001) Pre-Employment Health Assessment for Food Handlers: A Survey of Occupational Physicians in the Food Industry. Occupational Medicine, 5, 332-335. http://dx.doi.org/10.1093/occmed/51.5.332

[11] Government of Western Australia (2015) Guidelines for Exclusion of People with Enteric Infections and Their Contacts from Work, School and Child-Care Settings. Department of Health, 1-3.

[12] Finkelstein, R.A. (1996) Vibrio cholera O1 and O139, and Other Pathogenic Vibrios. In: Baron, S., Ed., Medical Microbiology, 4th Edition, Chapter 24 (Cholera).

[13] Qu, M., Xu, J., Ding, Y., Wang, R., Liu, P., Kan, B., Qi, G., Liu, Y. and Gao, S. (2003) Molecular Epidemiology of Vibrio cholera O139 in China: Polymorphism of Ribotypes and CTX Elements. Journal of Clinical Microbiology, 41, 2306-2310. http://dx.doi.org/10.1128/JCM.41.6.2306-2310.2003

[14] USAID-United State Academy International Development (2014) Iraq Standard Operating Procedures, SOP: NCL BE 001, Laboratory Identification of Vibrio Cholera. National Cholera Laboratory IRAQ, 1-31.

[15] Al-Naddawi, T.H. (2010) Molecular Epidemiology of Vibrio cholera in Iraq during Outbreaks 2007 to 2009. Ph.D. Thesis, College of Science, University of Baghdad, Baghdad.

[16] Weber, G.G., Kortmann, J., Narberhaus, F. and Klose, K.E. (2014) RNA Thermometer Controls Temperature- Dependent Virulence Factor Expression in Vibrio cholera. Proceedings of the National Academy of Sciences of the United States of America, 111, 14241-14246. http://dx.doi.org/10.1073/pnas.1411570111

[17] Fan, F., Liu, Z., Jabeen, N., Birdwell, L.D., Zhu, J. and Kan, B. (2014) Enhanced Interaction of Vibrio cholerae Virulence Regulators TcpP and ToxR under Oxygen-Limiting Conditions. Infection and Immunity, 82, 1676-1682. http://dx.doi.org/10.1128/IAI.01377-13

[18] Koskela, K.A., Matero, P., Blatny, J.M., Fykse, E.M., Olsen, J.S., Nuotio, L.O. and Nikkari, S. (2009) A Multiplatform Real-Time Polymerase Chain Reaction Detection Assay for Vibrio cholera. Diagnostic Microbiology and Infectious, 
65, 339-344. http://dx.doi.org/10.1016/j.diagmicrobio.2009.07.009

[19] Waturangi, D.E. and Fransiscal, M. (2009) Rapid Detection of Virulence Genes in Vibrio cholerafrom Edible Ice in Jakarta. Microbiology Indonesia, 3, 133-138. http://dx.doi.org/10.5454/mi.3.3.7

[20] Shrestha, S.D., Malla, S., Adhikari, B.R., Shakya, G., Basnyat, S.R. and Sharma, S. (2010) Antibiotic Susceptibility Patterns of Vibrio cholera Isolates. Journal of the Nepal Medical Association, 49, 232-236.

[21] Jones, T.F. (2012) How Useful Are Stool Studies for Acute Gastroenteritis? Journal of Infectious Diseases, 205, 13341335. http://dx.doi.org/10.1093/infdis/jis215

[22] Symington, V. (2011) Death by Diarrhea. In: Burdass, D., Ed., Cholera, Society for General Microbiology, 1-11.

[23] WHO (World Health Organization) (2014) Use of Antibiotics for Cholera. Last update—5 March

[24] Saleh, T.H., Sabbah, M.A., Jasem, K.A. and Hammad, Z.N. (2011) Identification of Virulence Factors in Vibrio cholera Isolated from Iraq during the 2007-2009 Outbreak. Canadian Journal of Microbiology, 57, 1024-1031. http://dx.doi.org/10.1139/w11-094

[25] Keddy, H.K., Sooka, A., Parsons, M.B., Lafourcade, B.M.N., Fitchet, K. and Smith, A.M. (2013) Diagnosis of Vibrio cholera O1 Infection in Africa. Journal of Infectious Diseases, 208, S23-S31. http://dx.doi.org/10.1093/infdis/jit196

[26] Buss, S.N., Leber, A., Chapin, K., Fey, P.D., Bankowski, M.J., Jones, M.K., Rogatcheva, M., Kanack, K.J. and Bourzac, K.M. (2015) Multicenter Evaluation of the BioFire Film Array Gastrointestinal Panel for Etiologic Diagnosis of Infectious Gastroenteritis. Journal of Clinical Microbiology, 53, 915-925. http://dx.doi.org/10.1128/JCM.02674-14

[27] Keasler, S.P. and Hall, R.H. (1993) Detecting and Biotyping Vibrio cholera O1 with Multiplex Polymerase Chain Reaction. Lancet, 341, 1661. http://dx.doi.org/10.1016/0140-6736(93)90792-F

[28] Khwaif, J.M., Hayyawi, A.H. and Yousif, T.I. (2010) Cholera Outbreak in Baghdad in 2007: An Epidemiological Study. Eastern Mediterranean Health Journal, 16, 460-465.

[29] WHO (World Health Organization) (2003) Communicable Disease Profile of Iraq.

[30] WHO (World Health Organization) (2012) Cholera in Iraq 2012.

[31] Emch, M., Feldacker, C., Islam, M.S. and Ali, M. (2008) Seasonality of Cholera from 1974 to 2005: A Review of Global Patterns. International Journal of Health Geographics, 7, 31. http://dx.doi.org/10.1186/1476-072X-7-31

[32] Al-Abbasi, A.R.M. and Aema, S.M. (2015) THE Cholera Epidemic in Iraq during 2015. Tofiq Journal of Medical Sciences, 2, 27-41. http://tjms.tofiq.org/tjms/article/view/48

[33] Saeed, B.H.M. (2008) A Study of Vibrio cholera Infection in Children. Iraqi Journal of Community Medicine, 21, 1823.

[34] Paddock, C. (2014) Iraq Prepares for Cholera, Diarrheal Disease Outbreaks. http://www.medicalnewstoday.com/articles/279058.php

[35] Jawetz, J.B., Melnick, J.L. and Adelbergg's, E.A. (2016) Vibrio, Campylobacters, Helicobacter and Associated Bacteria. In: Carroll, K.C., Brook, G.A., Miller, S., Morse, S.A., Mietzner, T.A., Detrick, B., Mitchell, T.G., McKerrow, J.H. and Sakanari, J.A., Eds., Jawetz, Melnick, \& Adelberg's Medical Microbiology, 27th Edition, Section III Bacteriology, Chapter 17, McGraw-Hill Education, New York, 253-256.

[36] Auda, I.G. and Al-kadmy, I.M. (2014) Toxigenic Potential of Vibrio cholera O1 and O139 Serotypes Isolated from Cases of Diarrhea in Baghdad Hospitals. Journal of Biotechnology Research Center, 8, 84-89.

[37] Alaouadi, R.F. (2014) Frequency of V. cholera in Babylon Province. Journal of Babylon University/Pure and Applied Sciences, 22, 2579-2590.

[38] WHO (World Health Organization) (2003) Global Salm-Surv. A Global Salmonella Surveillance and Laboratory Support Project of the WHO. Laboratory Protocols Level 1 Training Course: Isolation of Salmonella. Edited by Hendriksen, R.S. (DFVF), 4th Edition, 1-19.

[39] Mikoleit, M.L. (2010) WHO Global Foodborne Infections Network. "A WHO Network Building Capacity to Detect, Control and Prevent Foodborne and Other Enteric Infections from Farm to Table" Laboratory Protocol: "Isolation of Salmonella and Shigella from Faecal Specimens”. Enteric Diseases Laboratory Branch Centers for Disease Control and Prevention, Atlanta.

[40] Acharya, T. (2013) Vibrio Cholera Laboratory Diagnosis and Confirmation. Online Medical Microbiology Guide for Student. Laboratory Diagnosis of Bacterial Disease.

[41] Samanta, P., Ghosh, P., Chowdhury, G., Ramamurthy, T. and Mukhopadhyay, A.K. (2015) Sensitivity to Polymyxin B in El Tor Vibrio cholera O1 Strain, Kolkata, India. Emerging Infectious Diseases, 21, 2100-2102. http://dx.doi.org/10.3201/eid2111.150762

[42] Sirinavin, S. and Garner, P. (2000) Antibiotics for Treating Salmonella Gut Infections. The Cochrane Database of Systematic Reviews, 2, Article ID: CD001167. http://www.ncbi.nlm.nih.gov/pubmed/10796610 
[43] Shiferaw, B., Solghan, S., Palmer, A., Joyce, K., Barzilay, E.J., Krueger, A. and Cieslak, P. (2012) Antimicrobial Susceptibility Patterns of Shigella Isolates in Foodborne Diseases Active Surveillance Network (FoodNet) Sites, 2000-2010. Clinical Infectious Diseases, 54, S458-S463. http://dx.doi.org/10.1093/cid/cis230

[44] Klochko, A., Bronze, M.S., Wallace, M.R., Talavera, F., Brusch, J.L. and Nettleman, M.D. (2015) Salmonellosis Treatment and Management (Medical Care). http://emedicine.medscape.com/article/228174-treatment

[45] Fields, P.I., Popovic, T., Wachsmuth, K. and Olsvik, O. (1992) Use of Polymerase Chain Reaction for Detection of Toxigenic Vibrio cholera O1 Strains from the Latin American Cholera Epidemic. Journal of Clinical Microbiology, 30, 2118-2121.

[46] Rivera, I.N.G., Chun, J., Huq, A., Sack, R.B. and Colwell, R.R. (2001) Genotype Associated with Virulence in Environmental Isolates of Vibrio cholera. Applied and Environmental Microbiology, 67, 2421-2429. http://dx.doi.org/10.1128/AEM.67.6.2421-2429.2001

[47] Goel, A.K., Ponmariappan, S., Kamboj, D.V. and Singh, L. (2007) Single Multiplex Polymerase Chain Reaction for Environmental Surveillance of Toxigenic-Pathogenic O1 and Non-O1 Vibrio cholera. Folia Microbiologica (Praha), 52, 81-85. http://dx.doi.org/10.1007/BF02932143

[48] Nair, G.B., Faruque, S.M., Bhuiyan, N.A., Kamruzzaman, M., Siddique, A.K. and Sack, D.A. (2002) New Variants of Vibrio cholera O1 Biotype El Tor with Attributes of the Classical Biotype from Hospitalized Patients with Acute Diarrhea in Bangladesh. Journal of Clinical Microbiology, 40, 3296-3299. http://dx.doi.org/10.1128/JCM.40.9.3296-3299.2002

[49] Keramat, F., Hashemi, S.H., Mamani, M., Ranjbar, M. and Erfani, H. (2008) Survey of Antibiogram Tests in Cholera Patients in the 2005 Epidemic in Hamadan, Islamic Republic of Iran. Eastern Mediterranean Health Journal, 14, 768775.

[50] Jabeen, K., Zafar, A. and Hasan, R. (2008) Increased Isolation of Vibrio cholera O1 Serotype Inaba over Serotype Ogawa in Pakistan. Eastern Mediterranean Health Journal, 14, 564-570.

[51] Taneja, N., Mishra, A., Sangar, G., Singh, G. and Sharma M. (2009) Outbreaks Caused by New Variants of Vibrio cholera O1 El Tor, India. Emerging Infectious Diseases, 15, 352-354. http://dx.doi.org/10.3201/eid1502.080943

[52] Okada, K., Chantaroj, S., Roobthaisong, A., Hamada, S. and Sawanpanyalert, P. (2010) A Cholera Outbreak of the Vibrio cholera O1 El Tor Variant Carrying Classical ctxB in Northeastern Thailand in 2007. The American Journal of Tropical Medicine and Hygiene, 82, 875-878. http://dx.doi.org/10.4269/ajtmh.2010.09-0537

[53] Teh, C.S.J., Suhaili, Z., Lim, K.T., Khamaruddin, M.A., Yahya, F., Sajili, M.H., Yeo, C.C. and Thong, K.L. (2012) Outbreak-Associated Vibrio cholera Genotypes with Identical Pulsotypes, Malaysia, 2009. Emerging Infectious Diseases, 18, 1177-1179. http://dx.doi.org/10.3201/eid1807.111656

[54] Mzee, S., Chowdhury, N., Awasthi, S.P., Asakura, M., Hinenoya, A., Iijima, Y. and Shinji Yamasaki, S. (2014) Prevalence of Vibrio cholera O1 El Tor Variant in a Cholera-Endemic Zone of Kenya. Journal of Medical Microbiology, 63, 415-420. http://dx.doi.org/10.1099/jmm.0.068999-0

[55] Hasson, S.O., Al-Khafagi, Z.A. and Hendi, N.K. (2012) Study of Vibrio cholera with Its Virulence Factors Isolated from Diarrheal Patients in Babylon Province. Medical Journal of Babylon, 9, 152-158.

[56] Nesper, J., Lauriano, C.M., Klose, K.E., Kapfhammer, D., Kraiss, A. and Reidl, J. (2001) Characterization of Vibrio cholera $\mathrm{O} 1 \mathrm{El}$ Tor galU and galE Mutants: Influence on Lipopolysaccharide Structure, Colonization, and Biofilm Formation. Infection and Immunity, 69, 435-445. http://dx.doi.org/10.1128/IAI.69.1.435-445.2001

[57] Dougan, G., Huett, A. and Clare, S. (2002) Vaccines against Human Enteric Bacterial Pathogens. British Medical Pulletin, 62, 113-123. http://dx.doi.org/10.1093/bmb/62.1.113

[58] Al-Naddawi, M.N. and Khalid, Z.H. (2009) A Clinical Study of Vibriosis during 1999 in Al-Mansour Childrens' Teaching Hospital. The Iraq Postgraduate Medical Journal, 8, 148-152.

[59] Kadhim, S.A. and Saleh, D.S. (2010) Detection of Some Bacterial Causes of Watery Diarrhea in the Province of Baghdad and Some Northern Governorates with a Study of Pathological Effects. Iraqi Journal of Science, 53, 536-543.

[60] Al-Abbassi, A.M., Ahmed, S. and Al-hadithi, T. (2005) Cholera Epidemic in Baghdad during 1999: Clinical and Bacteriological Profile of Hospitalized Cases. Eastern Mediterranean Health Journal, 11, 6-13.

[61] Talkington, D., Bopp, C., Tarr, C., Parsons, M.B., Dahourou, G., Freeman, M., Joyce, K., Turnsek, M., Garrett, N., Humphrys, M., Gomez, G., Stroika, S., Boncy, J., Ochieng, B., Oundo, J., Klena, J., Smith, A., Keddy, K. and Smidt, P.G. (2011) Characterization of Toxigenic Vibrio cholera from Haiti, 2010-2011. Emerging Infectious Diseases, 17, 2122-2129. http://dx.doi.org/10.3201/eid1711.110805

[62] Lipp, E.K., Huq, A. and Colwell, R.R. (2002) Effects of Global Climate on Infectious Disease: The Cholera Model. Clinical Microbiology Reviews, 15, 757-770. http://dx.doi.org/10.1128/CMR.15.4.757-770.2002

[63] Sack, R.B., Siddique, A.K., Longini, I.M., Nizam, A., Yunus, M.D., Islam, M.S., Morris, J.G., Ali, A., Huq, A., Nair, 
G.B., Qadri, F., Faruque, S.M., Sack, D.A. and Colwell, R.R. (2003) A 4-Year Study of the Epidemiology of Vibrio cholerain Four Rural Areas of Bangladesh. Journal of Infectious Diseases, 187, 96-101. http://dx.doi.org/10.1086/345865

[64] Colwell, R.R. and Spira, W.M. (1993) The Ecology of Vibrio cholera. In: Barua, D. and Greenough, W.B., Eds., Cholera: Current Topics in Infections Disease, 3rd Edition, Plenum Medical Book Co., New York, 3-60.

[65] Bowman, C., Flint, J. and Pollari, F. (2003) Canadian Integrated Surveillance Report: Salmonella, Campylobacter, Pathogenic E. coli and Shigella, from 1996 to 1999. Canadian Communicable Disease Report, 29, 1-6.

[66] Naumova, E.N., Jagai, J.S., Matyas, B., Demaria, A.J.R., Macneill, I.B. and Griffiths, J.K. (2007) Seasonality in Six Enterically Transmitted Diseases and Ambient Temperature. Epidemiology and Infection, 135, 281-292. http://dx.doi.org/10.1017/S0950268806006698

[67] Khudair, M.K., Jawad, S.J. and Nazal, M.F. (2011) Study the Causes of Parasitic Diarrhea in Children in Al-Ahded Village, Dyalagovernarate. Baghdad for Sciences Journal, 8, 887-890.

[68] Fleming, C.A., Caron, D., Gunn, J.E., Horine, M.S., Matyas, B.T. and Barry, M.A. (2000) An Outbreak of Shigella sonnei Associated with a Recreational Spray Fountain. American Journal of Public Health, 90, 1641-1642. http://dx.doi.org/10.2105/AJPH.90.10.1641

[69] Lee, S.H., Levy, D.A., Craun, G.F., Beach, M.J. and Calderon, R.L. (2002) Surveillance for waterborne-Disease Outbreaks-United States, 1999-2000. CDC/MMWR, Surveillance Summaries, 51, 1-28. http://mmwrq@cdc.gov

[70] Stuart, J.M., Orr, H.J., Warburton, F.G., Jeyakanth, S., Pugh, C., Morris, I., Sarangi, J. and Nichols, G. (2003) Risk Factors for Sporadic Giardiasis: A Case-Control Study in Southwestern England. Emerging Infectious Disease, 9, 229233. http://dx.doi.org/10.3201/eid0902.010488

[71] Gardner, T.B. and Hill, D.R. (2001) Treatment of Giardiasis. Clinical Microbiology Reviews, 14, 114-128. http://dx.doi.org/10.1128/CMR.14.1.114-128.2001

[72] Calzada, F., Cervantes-Martínez, J.A. and Yépez-Mulia, L. (2005) In Vitro Antiprotozoal Activity from the Roots of Geranium mexicanumand Its Constituents on Entamoeba histolytica and Giardia lamblia. Journal of Ethnopharmacology, 98, 191-193. http://dx.doi.org/10.1016/j.jep.2005.01.019

[73] WHO (World Health Organization) (2015) Cholera-Iraq. Disease Outbreak News 12 October. http://www.who.int/csr/don/12-october-2015-cholera/en/

[74] Guarino, A. and Giannattasio, A. (2011) New Molecular Approaches in the Diagnosis of Acute Diarrhea: Advantages for Clinicians and Researchers. Current Opinion Gastroenterology, 27, 24-29. http://dx.doi.org/10.1097/MOG.0b013e3283413750

[75] Operario, D.J. and Houpt, E. (2011) Defining the Etiology of Diarrhea: Novel Approaches. Current Opinion Infectious Diseases, 24, 464-471. http://dx.doi.org/10.1097/QCO.0b013e32834aa13a

[76] Al-Shok, M.M. and Baey, H.A. (2009) Clinical Study on Cholera Patients in Babylon. Medical Journal of Babylon, 6, 420-423.

[77] Uppal, B., Berry, N., Kahar, S. and Ramji, S. (1999) Vibrio cholera O1 Serotype Ogawa in Neonate. Diagnostic Microbiology and Infectious Disease, 33, 63-64. http://dx.doi.org/10.1016/S0732-8893(98)00131-X

[78] Elliot, E.L., Kaysner, C.A., Jackson, L. and Tamplin, M.L. (2001) Vibrio cholera, V. parahemolyticus, V. valnificus and other Vibrio spp. In: Merker, R.L., Ed., Food and Drug Administration: Bacteriological Analytical Manual, 8th Edition, Chapter 9, AOAC International, Gaithersburg.

[79] Faulkner, C.T., Garcia, B.B., Logan, M.H., New, J.C. and Patton, S. (2003) Prevalence of Endoparasitic Infection in Children and Its Relation with Cholera Prevention Efforts in Mexico. Revista Panamericana de Salud Pública, 14, 3141. http://dx.doi.org/10.1590/S1020-49892003000600006

[80] Slanthia, P. and Bansal, M.P. (1999) Incidence of Vibrio cholera in Different Age Groups and Sex in Aurangabad Province Isolated during January 1994 to December 1994. Indian Journal of Medical Sciences, 53, 349-351.

[81] Qureshi, K., Molbak, K., Sadstrom, A. and Kofoed, P. (2006) Breast Milk Reduces the Risk of Illness in chiLdren of Mothers with Cholera: Observation from an Epidemic of Cholera in Guinea-Bissau. Pediatric Infectious Disease Journal, 25, 1163-1166. http://dx.doi.org/10.1097/01.inf.0000246977.58697.a5

[82] Ali, M., Nelson, A.R., Lopez, A.L. and Sack, D.A. (2015) Updated Global Burden of Cholera in Endemic Countries. PLoS Neglected Tropical Diseases, 9, e0003832. http://dx.doi.org/10.1371/journal.pntd.0003832

[83] Dempouo Djomassi, L., Gessner, B.D. and Etoundi Mballa, G.A. (2013) National Surveillance Data on the Epidemiology of Cholera in Cameroon. The Journal of Infectious Disease, 208, S92-S97. http://dx.doi.org/10.1093/infdis/jit197

[84] DOVE (Delivering Oral Cholera Vaccine Project) (2015) Cholera Surveillance: Detecting and Reporting Cases. Updated September 9: 1-6 Johns Hopkins Bloomberg School of Public Health 615 N. Wolfe Street/E5537, Baltimore, MD 
21205, USA. https://www.stopcholera.org/.../cholera/.../stop_cholera

[85] Blacklock, A., Sesay, A., Kamara, A., Kamara, M. and Blacklock, C. (2015) Characteristics and Clinical Management of Patients Admitted to Cholera Wards in a Regional Referral Hospital during the 2012 Epidemic in Sierra Leone. Global Health Action, 8, 25266. http://dx.doi.org/10.3402/gha.v8.25266

[86] Yadava, J.P., Jain, M. and Goel, A.K. (2013) Detection and Confirmation of Toxigenic Vibrio cholera O1 in Environmental and Clinical Samples by a Direct Cell Multiplex PCR. Water SA, 39, 611-614. http://dx.doi.org/10.4314/wsa.v39i5.4

[87] Ramazanzadeh, R., Rouhi, S., Shakib, P., Shahbazi, B., Bidarpour, F. and Karimi, M. (2015) Molecular Characterization of Vibrio cholera Isolated from Clinical Samples in Kurdistan Province, Iran. Jundishapur Journal of Microbiology, 8, e18119. http://dx.doi.org/10.5812/jim.8(5)2015.18119

[88] Ratna, P.V.J., Sandjarara, T. and Rajkumar, S. (2015) Genotyping of Vibrio cholera Strains Based on the Cholera Toxin and Virulence Associated Genes. Indian Journal of Applied Research, 5, 197-198.

[89] Jain, M., Kumar, P. and Goel, A.K. (2016) Emergence of Tetracycline Resistant Vibrio cholera O1 Biotype El Tor Serotype Ogawa with Classical $c t x B$ Gene from a Cholera Outbreak in Odisha, Eastern India. Journal of Pathogens, 2016, Article ID: 1695410. http://dx.doi.org/10.1155/2016/1695410

[90] Matson, J.S., Withey, J.H. and Dirita, V.J. (2007) Regulatory Networks Controlling Vibrio cholera Virulence Gene Expression. Infection and Immunity, 75, 5542-5549. http://dx.doi.org/10.1128/IAI.01094-07

[91] Goel, A.K., Jain, M., Kumar, P. and Jiang, S.C. (2010) Molecular Characterization of Vibrio cholera Outbreak Strains with Altered El Tor Biotype from Southern India. World Journal of Microbiology and Biotechnology, 26, 281-287. http://dx.doi.org/10.1007/s11274-009-0171-7

[92] Bielawska-Drozd, A., Mirski, T., Bartoszcze, M., Cieslik, P., Roszkowiak, A. and Michalski, A. (2012) Development of Real-Time PCR Assay for Detection of Vibrio cholera. Polish Journal of Environmental Studies, 21, 279-288.

[93] Tirapattanun, A., Chomvarin, C., Wongboot, W. and Kanoktippornchai, B. (2015) Application of SYBR Green Real-Time PCR for Detection of Toxigenic Vibrio cholera O1 in the Aquatic Environment. Chiang Mai Journal of Science, 42, 588-598.

[94] Bakhshi, B., Pourshafie, M.R., Navabakbar, F., Tavakoli, A., Shahcheraghi, F., Salehi, M., Faradjzadegan, Z. and Zahraei, S.M. (2008) Comparison of Distribution of Virulence Determinants in Clinical and Environmental Isolates of Vibrio cholera. Iranian Biomedical Journal, 12, 159-165.

[95] Mukherjee, M., Kakarla, P., Kumar, S., Gonzalez, E., Floyd, J.T., Inupakutika, M., Devireddy, A.R., Tirrell, S.R., Bruns, M., He, G., Lindquist, I.E., Sundararajan, A., Schilkey, F.D., Mudge, J. and Varela, M.F. (2014) Comparative Genome Analysis of Non-Toxigenic Non-O1 versus Toxigenic O1 Vibrio cholera. Genomics Discovery, 2, 1-15. http://dx.doi.org/10.7243/2052-7993-2-1

[96] Stonehouse, E., Kovacikova, G., Taylor, R.K. and Skorupski, K. (2008) Integration Host Factor Positively Regulates Virulence Gene Expression in Vibrio cholera. Bacteriology, 190, 4736-4748. http://dx.doi.org/10.1128/JB.00089-08

[97] Anvari, S., Najar, P.S., Behmanesh, M. and Boustanshenas, M. (2012) Biological Activity of Recombinant Accessory Cholera Enterotoxin (Ace) on Rabbit Illeal Loops and Antibacterial Assay. Cell Journal, 14, 209-214.

[98] Al-Obidi, I.M. (2005) Determination of Some Epidemiological Markers in Locally Isolated Vibrio cholera. MSc Thesis, College of Science, University of AL-Mustansiryah, AL-Mustansiryah.

[99] Duval, P., Chametier, R.G., Ranjalahy, J., Quilici, M.L. and Fournier, J.M. (1999) Cholera in Madagascar. Lancet, 353, 2068. http://dx.doi.org/10.1016/S0140-6736(99)00103-8

[100] Hochhut, B., Lotfi, Y., Mazel, D., Faruque, S.M., Woodgate, R. and Waldor, M.K. (2001) Molecular Analysis of Antibiotic Resistance Gene Clusters in Vibrio cholera O139 and O1 SXT Constins. Antimicrobal Agents Chemotherapy, 45, 2991-3000. http://dx.doi.org/10.1128/AAC.45.11.2991-3000.2001

[101] Sjölund-Karlsson, M., Reimer, A., Folster, J.P., Walker, M., Dahourou, G.A., Batra, D.G., Martin, R., Joyce, K., Parsons, M.B., Boncy, J., Whichard, J.M. and Gilmour, M.W. (2011) Drug Resistance Mechanisms in Vibrio cholera O1 Outbreak Strain, Haiti, 2010. Emerging Infectious Disease, 17, 2151-2154. http://dx.doi.org/10.3201/eid1711.110720

[102] Replogle, M.L., Fleming, D.W. and Cieslak, P.R. (2000) Emergence of Antimicrobial-Resistant Shigellosis in Oregon. Clinical Infectious Diseases, 30, 515-519. http://cid.oxfordjournals.org/content/30/3/515.long http://dx.doi.org/10.1086/313715

[103] Reller, M.E., Nelson, J.M., Mølbak, K., Ackman, D.M., Schoonmaker-Bopp, D.J., Root, T.P. and Mintz, E.D. (2006) A Large, Multiple-Restaurant Outbreak of Infection with Shigella flexneri Serotype 2a Traced to Tomatoes. Clinical Infectious Diseases, 42, 163-169. http://cid.oxfordjournals.org/content/42/2/163.long http://dx.doi.org/10.1086/498900 
[104] APHA (American Public Health Association) (2008) Shigellosis, in Control of Communicable Diseases Manual, Edited by Heymann, D.L., Presented by Clark, M., 19th Edition, 556-560. http://www.about-shigella.com/shigella_references

[105] Su, L.H., Chiu, C.H., Chu, C. and Ou, J.T. (2004) Antimicrobial Resistance in Non Typhoid Salmonella Serovars: A Global Challenge. Clinical Infectious Diseases, 39, 546-451. http://dx.doi.org/10.1086/422726

[106] Mijovic, G., Andric, B., Terzic, D., Lopicic, M. and Dupanovic, B. (2012) Antibiotic Susceptibility of Salmonella spp.: A Comparison of Two Surveys with a 5 Years Interval. Journal of IMAB, 18, 216-219. http://dx.doi.org/10.5272/jimab.2012181.216

\section{Submit or recommend next manuscript to SCIRP and we will provide best service for you:}

Accepting pre-submission inquiries through Email, Facebook, LinkedIn, Twitter, etc.

A wide selection of journals (inclusive of 9 subjects, more than 200 journals)

Providing 24-hour high-quality service

User-friendly online submission system

Fair and swift peer-review system

Efficient typesetting and proofreading procedure

Display of the result of downloads and visits, as well as the number of cited articles

Maximum dissemination of your research work

Submit your manuscript at: http://papersubmission.scirp.org/ 